\title{
Who Discovered the Northwest Passage?
}

\author{
Janice Cavell ${ }^{1}$
}

(Received 31 January 2018; accepted in revised form 1 May 2018)

\begin{abstract}
In 1855 a parliamentary committee concluded that Robert McClure deserved to be rewarded as the discoverer of a Northwest Passage. Since then, various writers have put forward rival claims on behalf of Sir John Franklin, John Rae, and Roald Amundsen. This article examines the process of 19th-century European exploration in the Arctic Archipelago, the definition of discovering a passage that prevailed at the time, and the arguments for and against the various contenders. It concludes that while no one explorer was "the" discoverer, McClure's achievement deserves reconsideration.
\end{abstract}

Key words: Northwest Passage; John Franklin; Robert McClure; John Rae; Roald Amundsen

RÉSUMÉ. En 1855, un comité parlementaire a conclu que Robert McClure méritait de recevoir le titre de découvreur d'un passage du Nord-Ouest. Depuis lors, diverses personnes ont avancé des prétentions rivales à l'endroit de Sir John Franklin, de John Rae et de Roald Amundsen. Cet article se penche sur l'exploration européenne de l'archipel Arctique au XIX ${ }^{\mathrm{e}}$ siècle, sur la définition de la découverte d'un passage en vigueur à l'époque, de même que sur les arguments pour et contre les divers prétendants au titre. Nous concluons en affirmant que même si aucun des explorateurs n'a été « le » découvreur, les réalisations de Robert McClure méritent d'être considérées de nouveau.

Mots clés : passage du Nord-Ouest; John Franklin; Robert McClure; John Rae; Roald Amundsen

Traduit pour la revue Arctic par Nicole Giguère.

\section{INTRODUCTION}

In 1855 a parliamentary committee declared that Captain Robert McClure had discovered the-or rather aNorthwest Passage. On the committee's recommendation, McClure and his men were awarded $£ 10000$ for their achievement. McClure himself received a knighthood. But even before these awards were made, the decision was controversial, and McClure is now seldom if ever credited as the discoverer. Over the years Sir John Franklin, John Rae, and Roald Amundsen have all had their champions, and no consensus has yet emerged.

There are several Northwest Passages, and the 19th-century definition of discovering a passage involved both geography and navigation (Fig. 1). That the process of discovery extended over many decades and was carried out by several different forms of travel adds further complications. This article outlines the stages of exploration and the claims put forward by explorers (or by their supporters). It concludes that it is impossible to single out one individual as the passage's true discoverer, but McClure's claim deserves more attention than it has received since the 1850s.

\section{THE SEARCH FOR THE PASSAGE BY SHIP AND BOAT, 1818-39}

The search for the passage was renewed in 1818, at the urging of Admiralty official John Barrow. Conveniently, the government provided a definition of discovery when it passed an act that both confirmed and modified a longstanding award of $£ 20000$, first offered in 1745 . Under the new act, anyone who could "find out and sail through" a northern channel all the way from Atlantic to Pacific would still receive $£ 20000$, but "proportionate rewards" were introduced for those who first "accomplished certain portions" of the passage (United Kingdom, Parliament, 1818). The details were worked out by the Board of Longitude and authorized by an order-in-council (United Kingdom, Privy Council, 1819). Increments of $£ 5000$ were offered for passing meridians $110^{\circ}, 130^{\circ}$, and $150^{\circ} \mathrm{W}$. Once these three rewards were collected, the explorer who completed the last stage would receive only the remaining $£ 5000$ (United Kingdom, Parliament, 1821).

The key criteria, then, were geographically discovering all or part of a passage and demonstrating that it was navigable for ships by actually sailing through it. The

\footnotetext{
${ }^{1}$ Department of History, Carleton University, 1125 Colonel By Drive, Ottawa, Ontario K1S 5B6, Canada; Janice.Cavell@carleton.ca (C) The Arctic Institute of North America
} 
introduction of the intermediate awards raised the possibility that the explorer who first reached the Pacific through the Arctic would share the financial prize equally with three others. In terms of money, the last stage was worth no more than the first. Indeed, if one explorer reached the first three milestones and another completed the passage, the first captain's monetary reward would be much greater than his successor's. Whether the fame would be shared in the same way was naturally not considered in the official documents, although the explorers themselves must have wondered.

The first effort was led in 1818 by John Ross, who turned back at the entrance to Lancaster Sound, believing it was a dead end. During his 1819-20 voyage in Hecla and Griper, Edward Parry sailed through Lancaster Sound and its continuation, Barrow Strait, as far as Melville Island. He was stopped just off the Dundas Peninsula by exceptionally heavy pack ice. This ice, he recorded (1821:250), "was as solid and compact, to all appearance, as so much land." Parry therefore returned to England, where he claimed the first of the $£ 5000$ awards. The scheme was then altered and enriched, with $£ 5000$ for passing $130^{\circ} \mathrm{W}, £ 5000$ for passing $150^{\circ} \mathrm{W}$, and $£ 10000$ for reaching the Pacific (United Kingdom, Privy Council, 1821).

Parry suspected that he had nearly accomplished the passage, but he also knew that such ice as he had seen near Melville Island might be a permanent barrier. Parry had in fact almost reached the Beaufort Sea, which was the source of the heavy ice. But, he reasoned, there must be another passage in a lower latitude, where ice conditions would be better. Moreover, Parry had found that the best way to navigate through Arctic waters was near a coastline, in water deep enough for ships but shallow enough that heavy ice would be grounded well offshore, leaving a lane of comparatively open water. Along the coast of the continent, explorers could be "sure that the land will not fail us" (Parry, 1821:298).

Parry made his next effort through Hudson Strait and Fury and Hecla Strait, but was again blocked by ice. On his third voyage, he tried Prince Regent Inlet, but lost one of his ships and was forced to return. Many explorers hoped that the land on the west side of this inlet (later called Boothia) was an island, and that it would be possible to follow the coastline from the bottom of the Gulf of Boothia westward to the Bering Strait. In 1829-33 John Ross made another attempt through Prince Regent Inlet, but he did not get far enough south to clear this question up. His nephew, James Clark Ross, traveled to the western coast of Boothia and reached King William "Land" (actually an island), which he believed was connected with Boothia.

In 1819 Barrow had decided to supplement Parry's explorations from the east with modest but potentially useful efforts in the western Arctic. John Franklin had accordingly carried out two overland expeditions that reached the Arctic Ocean via the Coppermine River in 1819-22 and the Mackenzie River in 1825-27, then surveyed the continental coast in boats. On his first expedition, Franklin traveled as far east as the Kent Peninsula; on the second, Franklin himself went west, past the Alaska border, while another party led by John Richardson sailed east from the mouth of the Mackenzie to the mouth of the Coppermine. During this boat voyage, Richardson passed the next intermediate milestone, longitude $130^{\circ} \mathrm{W}$. But, as he regretfully observed (in Franklin, 1828:258), because "it was not contemplated, in framing the Order, that the discovery should be made from west to east, and in vessels so small," he "could not lay claim to the pecuniary reward." Franklin correctly believed that the waters charted during his expeditions were navigable by ships, yet navigation had taken place only in boats. In 1828 the remaining awards were canceled, probably as a result of this development.

After 1828, naval exploration in the Arctic ceased for several years. Ross's expedition to Prince Regent Inlet was privately sponsored, as was George Back's journey down the Great Fish (Back) River in 1833-35, which was initially intended to be a search for the long-absent Ross. Back received word of Ross's safe return to England during the early part of his journey, and therefore he was instructed by the committee in charge of the expedition to first survey the Arctic coast westward as far as Franklin's Point Turnagain on the Kent Peninsula, then attempt to connect that coast with the Rosses' discoveries (Back, 1836:19). Ice conditions prevented even the first attempt, but looking east from the mouth of Chantrey Inlet, Back (1836:425) saw what he described as "strong inferences in favour of the existence of a southern channel to Regent's Inlet."

Back had at least established that the coast at the mouth of the Back River was in roughly the same latitude as Point Turnagain. The interest aroused by this result was great enough to win approval for a new Admiralty expedition, intended to chart the coast between Prince Regent Inlet and Point Turnagain. In 1836 Back was instructed to sail to the northwest corner of Hudson Bay, then travel overland from there to the Gulf of Boothia (Back, 1838:1, 6-15). However, the ice was exceptionally bad in that year. Back's ship, Terror, was severely damaged and the overland attempt never took place.

The unknown coast from Point Turnagain to just beyond Chantrey Inlet was finally charted by two Hudson's Bay Company (HBC) employees, Peter Warren Dease and Thomas Simpson, during boat expeditions in 1838 and 1839. After reaching the area previously visited by Back and proceeding a little farther east, they too thought they saw a way into the Gulf of Boothia ahead of them. Dease and Simpson landed on the southwest coast of King William Island, believing it was part of Boothia, and built a large cairn at Cape Herschel (Simpson, 1843:371-380). Simpson intended to return the next year and continue into the Gulf of Boothia (Simpson, 1845:329, 340-344), but in the interim, he died.

Even though Boothia is actually a peninsula, not an island, Dease and Simpson had come very close to joining their discoveries with those made by Parry's second and third expeditions and by the Rosses. Contrary to the 

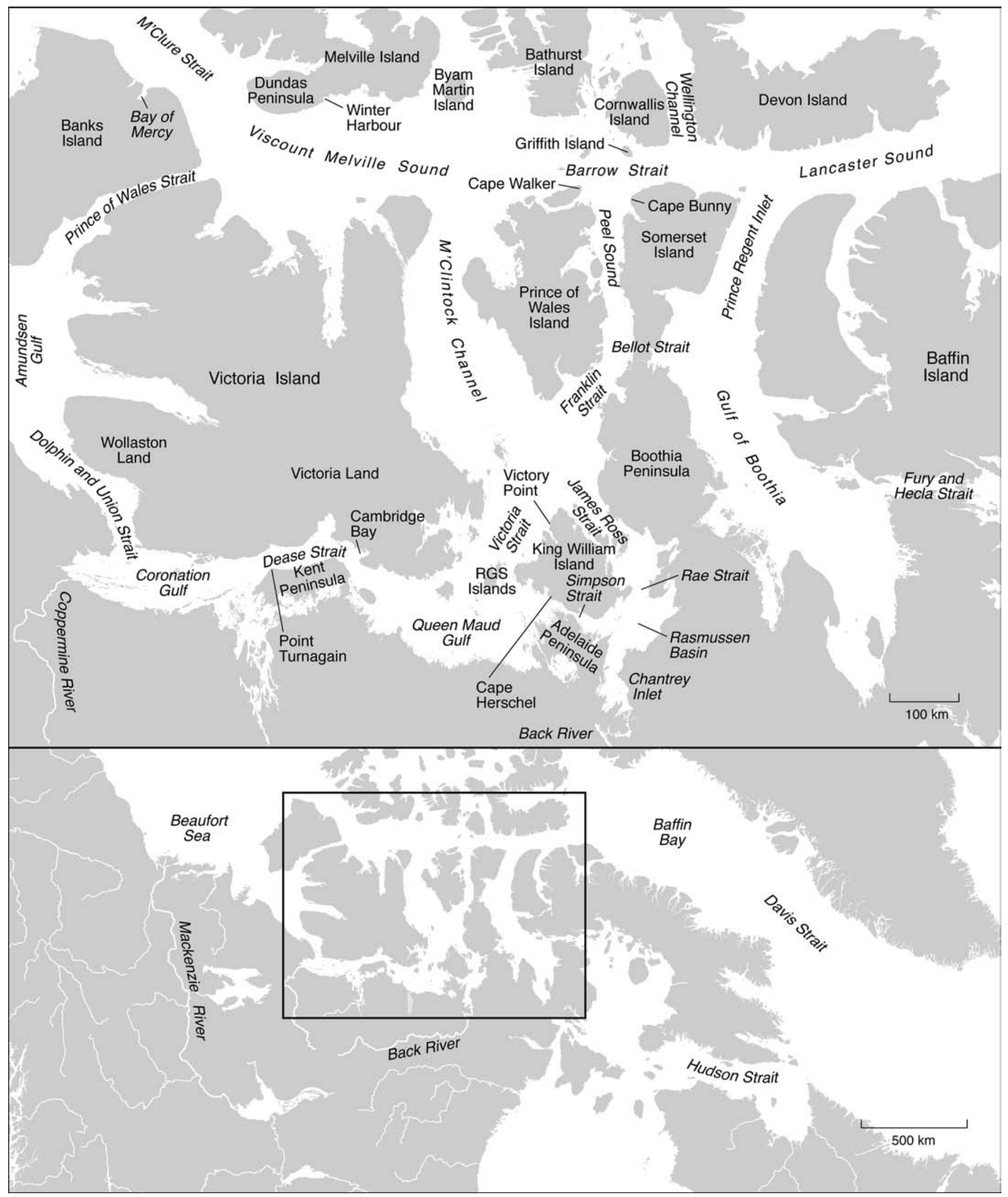

FIG. 1. Arctic Archipelago: Northwest Passage area. (Map by Eric Leinberger.) 
expectations held in 1818, after Parry's first voyage efforts from the east in ships had made only modest advances. In contrast, boat exploration from the west had been outstandingly successful. Given this situation, it might well have been asked whether discovering the Northwest Passage still meant sailing all the way through it in a ship.

The framers of the 1818 award scheme had envisioned an east-to-west process of discovery in which the last explorer would voyage into the final remaining unknown area, then emerge through the Bering Strait. But now both the eastern and the western ends had been charted, and an unknown "last link"- to quote a famous phrase-lay somewhere between them. It was possible that the next explorer might join the known area in the east with the known area in the west, establishing the fact that a water connection between Atlantic and Pacific did exist north of the continent. This would be a key geographical discovery. However, if the geographical puzzle was solved without navigation in ships, even if soundings or other observations indicated navigability, then according to the logic employed in 1818 the Northwest Passage would be known, yet not truly discovered. But must the 1818 criteria still be applied?

Dease and Simpson themselves believed they had discovered the passage, and Simpson's memorial tablet praised him for this feat (Simpson, 1845:328, 397-402; Barr, 2000:114-115). If a strait between Boothia and the mainland had in fact proved to be the last link, the claim might have received attention in later years, but since there is no such channel, it was forgotten.

\section{A NEW SHIP EXPEDITION, 1836-48}

During the 1830s, Barrow envisioned a new ship expedition that would begin by following Parry's original route through Lancaster Sound and Barrow Strait, then turn southwest toward the Bering Strait. On his voyages to and from Melville Island in 1819-20, Parry had found land both north and south of the waters now collectively known as Parry Channel. On the northern side, he saw and named North Devon (Devon Island) and Cornwallis, Bathurst, and Byam Martin Islands, plus many smaller islands (Fig. 1). He observed that the passage to the north between North Devon and Cornwallis Island, which he named Wellington Channel, appeared to be free of ice. On the south side, the land west of Prince Regent Inlet was glimpsed only intermittently. Parry gave this land the general name of North Somerset. Two prominent capes were named Bunny and Walker. Parry thought there was likely a southwardleading channel west of Cape Bunny. West of Cape Walker the southern land disappeared altogether; there, although Parry did not realize it, Parry Channel widens out into Viscount Melville Sound. Finally, southwest of Melville Island, Parry saw a coast to which he gave the name Banks Land (Parry, 1821:52-74, 238, 265).

Barrow was convinced that west and south of Cape Walker there was only open sea except for Banks Land,
Wollaston Land, and Victoria Land, all of which he assumed were comparatively small. The two latter lands had been sighted by Richardson and Simpson, respectively, and were in fact the southwestern and southeastern parts of Victoria Island, which occupies most of the area thought by Barrow to be water. Barrow scoffed at Parry's belief that safe navigation was possible only along a coastline; instead, he proposed that a route be sought directly from Cape Walker to the Bering Strait (Barrow et al., 1836:36-37).

In 1836, the Royal Geographical Society (RGS) asked Franklin, Richardson, and John Ross to comment on Barrow's proposal. Franklin recommended that the survey of the continental coast from the Gulf of Boothia to Point Turnagain be completed first. The same expedition could explore from Boothia to Cape Walker "and thereby gain well-grounded information" to guide the ships that Franklin hoped would later be sent in search of the passage (Barrow et al., 1836:45). Richardson agreed with this plan, and he also thought there should be further surveys in the western Arctic, including investigation of Wollaston Land. There was, he observed (Barrow et al., 1836:40), no need for open sea in the unknown space to make the Northwest Passage practicable; rather, the discovery of a strait leading southwest from Cape Walker could also mean success. Richardson thought it best to determine the route before sending out two ships-preferably with steam power, so they could push through ice in a narrow channel- to navigate it.

Finally, John Ross criticized Barrow but endorsed Franklin's and Richardson's plans. He opined that there was continuous land west of Cape Walker. His reason for this belief was that the Melville Island ice drifted east through Barrow Strait. Since the prevailing winds were from the northwest, he thought it would go south instead unless blocked by land. According to Ross (Barrow et al., 1836:50), success would most likely be achieved "by keeping close to the shore, from Cape Walker, westward." But unknown to Ross, although much ice drifted through Barrow Strait, even more was carried southeast through M'Clintock Channel.

The RGS recommended Franklin's proposal to the government, and the result was Back's abortive 1836-37 attempt (see above). However, the instructions did not include exploration towards Cape Walker. After Back's failure, Barrow was eager to go ahead without further reconnaissance. Action in the north was delayed by James Ross's voyage to the Antarctic in HMS Erebus and HMS Terror. In December 1844, Barrow finally put forward a new Arctic proposal (in Cyriax, 1939:18-20). The expedition would use Ross's ships, which had been strengthened for their Antarctic venture. Confident that the Erebus and Terror could plunge into the unknown without significant danger, Barrow did not modify his 1836 plan.

Although Franklin agreed with Barrow that he should turn southwest after passing Cape Walker, he had very different-and far more accurate-expectations about what he would find there. As he explained in several letters 
written during the early part of his voyage $(1845 \mathrm{a}, \mathrm{b}, \mathrm{c})$, because Parry had seen muskoxen on Melville Island, Franklin was convinced there must be extensive land between the continent and Parry's discoveries, providing "a track ... not greatly broken by wide channels of water" (Franklin, 1845b).

There was, Franklin hoped, a strait between Banks Land and Wollaston Land that would lead him to the southwest. In other words, his goal was to find what is now called Prince of Wales Strait, which would indeed have been an ideal route. Anticipating the need to push through ice in a strait, he insisted that the ships be equipped with auxiliary steam engines (Cyriax, 1939:24-25). Franklin did not say so, but he probably accepted John Ross's theory that land continued far west of Cape Walker. If Ross was right, then Franklin could sail between the shore and the ice until he reached the strait between this new land and Banks Land. But Ross was wrong, and the wide opening of M'Clintock Channel lay across Franklin's planned route.

Franklin's letter to Richardson (1845a) went into more detail than the others because Richardson believed the route through Prince Regent Inlet held great promise. Franklin, however, thought the Gulf of Boothia was probably too dangerous for ships. That area, he told Richardson, should be surveyed in boats. In addition, Franklin was not sure that any of the waters explored by Dease and Simpson (Dease Strait, Queen Maud Gulf, Simpson Strait, and the southern end of Rasmussen Basin) were navigable by ships. However, "once to the west of Point Turnagain our ships might with safety go." Franklin accordingly showed no interest in Parry's theory about a channel leading south from Cape Bunny, and in any case he agreed with James Ross, who believed the continental coast likely extended all the way from Boothia to Cape Walker $(1845 b, c)$.

Franklin's orders - which he no doubt helped to draftinstructed him not to examine any openings to either the north or the south until he reached Cape Walker. "From that point," the orders (United Kingdom, Admiralty, 1848) continued, "we desire that every effort be used to endeavour to penetrate to the southward and westward in a course as direct towards Bhering's Strait as the position and extent of the ice, or the existence of land, at present unknown, may admit." If Franklin could not progress in this direction, he was authorized to try Wellington Channel and look for a route north of Melville Island. Then he could winter at a spot of his choosing and decide his own course in the second season. As Franklin explained to his correspondents (see especially 1845b), with three years' supplies he would have time to try several routes. "I shall of course," he assured Richardson (1845a), "despatch parties in boats and by land to examine into and find out passages in places where it may be difficult $\&$ only productive of delay in taking the ships."

In the first year Franklin was unable to follow his preferred route, and he therefore sailed up Wellington Channel. After circumnavigating Cornwallis Island, he wintered at Beechey Island, near the southwestern corner of Devon Island. In 1846 he arrived off the north coast of King William Island by an unknown route. The ships wintered there in the ice. On 11 June 1847 Franklin died; on 22 April 1848 the men abandoned the ships, which had drifted slightly southwest into Victoria Strait. Led by Francis Crozier, they trekked down the west coast of King William Island toward Chantrey Inlet, apparently hoping to travel up the Back River to safety. On the way, they passed Dease and Simpson's cairn at Cape Herschel. The rest is conjecture.

Parry's hunch about a channel leading south from Cape Bunny was correct. The northern part of this channel is now called Peel Sound, while the southern part has been named Franklin Strait. During the Franklin search, Peel Sound was visited in $1849,1851,1852,1858$, and 1859 ; in each of these years it was solidly blocked with ice. West of Cape Walker, M'Clintock Channel leads south and then southeast, providing another possible route to King William Island. One of its shores was examined in 1851 and 1859. Since the ice conditions seen there were even worse than in Peel Sound, it has generally been assumed that Franklin must have found Peel Sound open for once. Then, confronted with the stream of ice pouring down M'Clintock Channel and into Victoria Strait, he supposedly chose to push his ships into this pack (Neatby, 1958:181; Savours, 1999:293; Williams, 2009:345, 355). Victoria Strait leads south to Queen Maud Gulf-east of the area where Franklin believed his ships could "with safety go." Such a move, then, would have been at odds with the intentions he had outlined to Richardson.

When Franklin's men passed Cape Herschel, discoveries from the east had finally overlapped with those from the west. Geographically, Victoria Strait was the last link in a chain of waters joining the Atlantic and the Pacific. However, even if Victoria Strait had been ice-free, Franklin himself would not have regarded reaching Cape Herschel as equivalent to discovering the Northwest Passage, because he was not sure the waters between Cape Herschel and Point Turnagain were navigable. Nevertheless, when his expedition's story became known, Franklin was almost universally hailed as the discoverer. In terms of geography alone, the accolade was merited-although, since it was not clear whether Franklin was still alive when the link was confirmed, the title should have been shared with Crozier. However, Franklin and Crozier themselves would have been the first to acknowledge that their passage might not be navigable.

Whether the Erebus and Terror reached Victoria Strait by way of Peel Sound and Franklin Strait or by way of M'Clintock Channel might seem to be a minor question, but in fact it was central to the perception of Franklin as the hero of the Northwest Passage. This matter is discussed in detail below; here it is sufficient to observe that ice conditions on both routes were likely difficult in 1846 . If both were feasible, Franklin would have preferred M'Clintock Channel because it was farther west and might have led to the vicinity of Point Turnagain. But if 
there was clearly no possibility of progress by this route, he could indeed have tried Peel Sound, hoping it would turn westward. Or he might have realized the dangers of M'Clintock Channel too late-a forgotten theory that deserves reconsideration.

\section{THE SEARCH FOR FRANKLIN AND FOR THE PASSAGE, 1848-54}

When a search for Franklin was discussed in 1847, Richardson's first thought was that the ships had gone beyond Cape Walker, then been crushed by ice. He recommended (1848) that a boat expedition should check Wollaston and Victoria Lands for survivors. Richardson's proposal was approved, and he was joined by John Rae of the HBC, who had made an important coastal survey in 1846-47. Richardson and Rae searched the western continental coast, but were unable to cross to Wollaston Land in either 1848 or 1849 because of unusually heavy ice in Dolphin and Union Strait.

James Ross, meanwhile, proposed (1848) a two-ship eastern search. One ship would winter on Melville Island and then explore the coasts of Banks Land by sledge, possibly joining with Richardson's party; the other would try Wellington Channel, then winter on North Somerset and examine the nearby coasts. This plan was also approved, but to his astonishment, in 1848 Ross was unable to reach Melville Island, or even to pass from Lancaster Sound into Barrow Strait. Both his ships wintered at the entrance to Prince Regent Inlet.

From there, Ross sledged partway down the east coast of Peel Sound in 1849. His observations reduced Parry's North Somerset to what is now called Somerset Island. However, Ross did not realize it was an island, supposing instead that it was the northern end of Boothia. Nor did he realize that Peel Sound was a strait, because he could see only isolated points of land to the west. These appeared like scattered small islands, when in fact they were headlands on Prince of Wales Island. One of Ross's officers, Leopold McClintock, later recounted (1857a:195) that it seemed any attempt to take a ship into this area "would not only fail, but lead to almost inevitable risk of destruction" because of the exceptionally heavy ice.

The next eastern attempt was made by Horatio Austin with a squadron of ships in 1850-51. Like Ross, Austin could not reach Melville Island. He took up winter quarters at Griffith Island, south of Cornwallis Island. A sledge party under William Browne examined the west side of Peel Sound, which was given the name Peel Strait. Browne (1851:75) considered that "this channel is rarely, if ever, sufficiently open for the purposes of navigation." At the same time, on the other side of Prince of Wales Island, Sherard Osborn covered part of the eastern shore of M'Clintock Channel and reached a similar conclusion. He reported (1851:102; see also Barr, 2016) that "huge masses of ice" were pressed up into ridges, sometimes resembling "a heavy cross sea suddenly frozen solid." However, Osborn did not realize he was looking at a channel through which a large part of the Viscount Melville Sound ice was carried to the southeast. Instead, he thought it was a bay (later marked on some maps as Osborn Bay) and that Prince of Wales Island continued westward.

On his return to Griffith Island, Osborn (1852:222) was met with the news that open water had been found up Wellington Channel. Since all routes to the south seemed impassable, the attention of most explorers in the eastern Arctic was concentrated on Wellington Channel for the next few years.

There was, however, one more search in the vicinity of North Somerset. In 1851 Lady Franklin sent out an expedition commanded by William Kennedy. Because of continued unusual ice conditions in Barrow Strait, Kennedy was unable to get to Griffith Island and so was not aware of what Austin's men had done. He wintered in Prince Regent Inlet; from there he made his way to the southern end of Peel Sound on foot, following the narrow strait that divides Somerset Island from Boothia. Kennedy named it Bellot Strait.

From the western end of Bellot Strait he crossed Peel Sound over the ice, intent on reaching the area west of Cape Walker. Looking northward, Kennedy (1853:134) felt sure he saw land from one shore to another. He traveled to the west coast of Prince of Wales Island, then returned to the east coast - that is, to the west side of Peel Sound-well to the north of the place where he had first crossed from Somerset Island. Kennedy therefore unfortunately did not realize his earlier mistake. After his return, the name Peel Strait was changed to Peel Sound because of his report that the southern end was closed (McClintock, 1857a:195n).

A western ship expedition had set out in 1850. It consisted of two vessels, Enterprise, captained by Richard Collinson, and Investigator, captained by Robert McClure. The orders left the two leaders free to decide their own course once in the north. The ships separated during the outward voyage, and McClure - seemingly eager to operate independently of Collinson, his senior officer-rushed into the Arctic alone. He quickly discovered the southern part of Banks Island, then followed its eastern coast into Prince of Wales Strait. He wintered in the ice near the strait's northern end, and after a short sledge journey was able to confirm on 26 October 1850 that it opened into Viscount Melville Sound. Although Melville Island was not visible, the explorers' sight reportedly (Osborn, 1856:138) "embraced a distance which precluded the possibility of any land lying" between them and it. In $1851 \mathrm{McClure}$ sailed farther north, but still could not reach the sound by ship. In an extraordinarily bold move, he then turned south and went around the island to M'Clure Strait at its northern end, experiencing unprecedented danger from the heavy Beaufort Sea ice. Because the water was deep just off the northwestern coast, the ice was pressed very close to the land, leaving barely enough room for the Investigator to slip by. McClure was happy to take up winter quarters in 
the safety of a bay, to which he gave the apt name Bay of Mercy. From there, McClure sledged to Winter Harbour, Parry's old winter quarters on Melville Island, establishing beyond doubt that his discoveries and Parry's were connected by water.

McClure had found not one but two Northwest Passages - one of them the passage sought by Franklin. And unlike Franklin and Crozier, he knew the distance separating him from previously navigated waters was short. McClure desperately hoped to take his ship eastward and back to England, but the Investigator remained frozen in from the autumn of 1851 until the spring of 1853, when it was abandoned. McClure had left a message at Winter Harbour, which was found by a party from a new eastern expedition led by Sir Edward Belcher. Belcher's main purpose was to explore Wellington Channel, but Henry Kellett had been sent westward to look for Collinson and McClure with two ships, Resolute and Intrepid. McClure wanted to remain in the Investigator but Kellett, appalled by the crew's poor condition, would not permit it.

When the news reached England, Parry (in Anon., 1853) marveled that McClure had stood on "the very land I saw in coming from the eastward, but could not reach; so that there we are met within 60 miles." Nothing new would have been proved by taking the Investigator through waters already sailed by Parry. Nevertheless, the requirement for a discoverer to navigate the entire passage was firmly engrained in the minds of naval officers. McClure therefore fell back on the weak argument that he had traveled from Pacific to Atlantic, partly in different ships and partly on foot over a frozen channel. This claim won him a monetary award and his knighthood, but few Arctic experts were convinced. As a result, there has never been enough emphasis on the fact that McClure brought his ship very close to the farthest point reached by Parry's vessels, and that the intervening waters were quite certainly navigable when free (or partly free) of ice. The route west of Banks Island was clearly far too dangerous for any further attempts there, but Prince of Wales Strait was a different matter. In 1850 and 1851, Austin and Kennedy were unable to pass through an area that Parry had navigated with relative ease, so McClure's failure to get through in those years should not have been taken as proof that the strait's northern end was always blocked.

Collinson wintered in Hong Kong in 1850-51, then headed north and followed McClure's route up Prince of Wales Strait just after McClure himself had left it. The Enterprise reached the northern end of the strait, but could not pass through into Viscount Melville Sound. Collinson wintered on the west coast of Victoria Island and sent a sledge party to Melville Island. This journey confirmed beyond all doubt that Prince of Wales Strait was connected to the waters reached by Parry.

In 1852 Collinson sailed the Enterprise to Cambridge Bay on the southeast coast of Victoria Island, proving that much of Dease and Simpson's route was navigable. The next spring, he sledged along the island's east coast and came close to the scene of the Franklin tragedy, for he was on the west side of Victoria Strait. Collinson reached Gateshead Island (see McKenzie, 1975) at the junction of Victoria Strait and M'Clintock Channel. As he realized after finding a cairn and note near the farthest point of his journey, he had been preceded in the summer of 1851 by Rae, who had covered the same area by boat. It was Rae who bestowed the name Victoria Strait.

Both Rae and Collinson deduced that there was a water connection to Barrow Strait north of them. Rae (1852:93) noted that the flood tide came from the north, while Collinson (in United Kingdom, House of Commons, 1855:32) observed that the ice was "pressed upon the shore from a northern direction." Collinson, who traveled in the spring, recorded fairly heavy ice in Victoria Strait, while Rae, traveling in the summer, did not. Both, however, observed unusually heavy floes at the junction with M'Clintock Channel (Rae, 1852:85-90; Collinson, 1889:288). Collinson (1854) thought there was likely a strait from this point to Cape Walker, and he hoped that Franklin had not entered it only to become trapped in the ice.

Neither Rae nor Collinson considered Victoria Strait unnavigable. Indeed, Collinson (in United Kingdom, House of Commons, 1855:31-32) was convinced there was no navigable passage through Viscount Melville Sound and therefore Victoria Strait and the waters west of Cape Bunny were the last links. He of course knew nothing about the reports by Browne and Kennedy, which might have modified his views. When the ice broke out of Cambridge Bay in the summer of 1853, Collinson initially intended to continue to the northeast. As he later recounted (1855:203), "our egress by Peel Inlet appeared to me quite as feasible as the western route." But after examining the ship's stores, he realized that the full allowance of coal for heating and cooking had not been loaded at the dockyard.

Collinson decided to return westward, where driftwood was abundant. One of his officers later claimed that this was merely an excuse, and that the captain was "running away" from danger (Barr, 2007:181). However, Collinson knew the discoveries he had already made would count for nothing because McClure and Rae had preceded him. He therefore had every motivation to attempt the Northwest Passage through Victoria Strait and Peel Sound. Given the possibility that he might be forced to spend yet another winter in the Arctic, Collinson's retreat was a rare example of caution even when daring might have made him famous.

Both Rae and Collinson picked up debris that evidently came from a Royal Navy ship, since it bore the government's "broad arrow" mark. However, neither man immediately associated these items with Franklin, reasoning instead that they might have drifted south from the search vessels in Barrow Strait. Collinson accordingly did not have the prospect of determining Franklin's fate to tempt him toward King William Island.

After his 1851 search, Rae returned to the task of surveying the remaining unknown continental coastline. To that end, in 1854 he traveled overland from Repulse Bay 
to the farthest point reached by Dease and Simpson (the Castor and Pollux River), intending to continue north to Bellot Strait. On the outward journey, he met an Inuk who told him that some white men had died far to the west. The man said he had never been in this place himself and could not guide Rae there. Rae then traveled along the east side of Rae Strait and realized that King William "Land" was an island.

Because of poor weather conditions, Rae doubted he could reach Bellot Strait, and he turned back. At Pelly Bay he again met Inuit. This time he obtained detailed information about the dead white men, and concluded that the place where they died must be Chantrey Inlet. He received the impression $(1855 \mathrm{~b}: 250-251)$ that the men had been seen alive on King William Island in the spring of 1850 , having abandoned their ships in the ice. Their corpses had reportedly been found in the summer of that year on the Adelaide Peninsula and Montreal Island.

Rae Strait was part of the route followed when Roald Amundsen navigated from Atlantic to Pacific in 1903-06. However, Rae's reports to the HBC and the RGS (1855a, b) said nothing whatever about the possibility of having found a link in the Northwest Passage. To the HBC, Rae emphasized his chagrin over the failure of his coastal survey, without any suggestion that the discovery of Rae Strait compensated for this disappointment. There was, indeed, no reason for him to consider Rae Strait in relation to the Northwest Passage problem. Peel Sound, which would also be part of Amundsen's route, had been declared a dead end by Kennedy. Even if Rae doubted Kennedy's report, on the evidence of his own eyes in 1851 he was more likely to have believed that the wider, and presumably much deeper, Victoria Strait was the logical next step for any navigator who managed to pass through Peel Sound. That he did so consider it was shown the next year.

\section{THE DEBATES OF 1855}

Belcher, Kellett, McClure, and Rae all returned to England in the autumn of 1854; Collinson too was back in 1855. McClure assiduously lobbied politicians for a monetary reward (Stein, 2015:237-238), but at the same time Rae's news inspired Lady Franklin, Richardson, and others, including Sir Roderick Murchison, the influential president of the RGS, to mount a rival claim on behalf of Franklin and his men. Peel Sound, some members of this group reasoned, must be a strait after all and navigable in some years. They all agreed that if the men of the Erebus and Terror died in Chantrey Inlet, then they had reached the area discovered by Back, Dease, and Simpson. Collinson had brought his ship almost to this point, and after his return he championed the idea that there was a navigable passage through Victoria Strait. McClure had confirmed the existence of his first passage in October 1850; if Franklin's men had reached the continent in the spring or summer of that year, they had priority.
In June 1855, the appointment of a parliamentary select committee to investigate McClure's claim was ordered. The committee's hearings were held in July. Before the first hearing, Franklin's supporters opened their campaign with a letter to the Times from Richardson (1855a). Richardson asserted that Franklin was the first discoverer of a Northwest Passage and McClure the second. That Franklin's ships had been abandoned "in a waterway continuous with the sea that washes the continent" was, he wrote, proved by the relics Collinson found near Cambridge Bay. Therefore, according to Richardson, Collinson might be considered a third discoverer. Richardson knew that Rae had retrieved other items two years before Collinson, and since he and Rae were on good terms, it is difficult to see why he gave the accolade to Collinson. Possibly the fact that Collinson had arrived in Cambridge Bay by ship influenced Richardson's thinking.

Rae penned an immediate response (1855c). He made no argument against Richardson's claims about Franklin and McClure, but wrote that there was "one portion" of Richardson's letter with which he could not agree. Collinson, Rae insisted, had "nothing but theory to guide him in supposing that a channel leading northward to Barrow's Strait existed," because he brought back no definitive tidal observations. Rae did not think mere deduction could entitle anyone "to stand number three on this list as discoverer of a north-west passage," but if such a criterion were accepted, then

I should certainly have priority to Captain Collinson, as I in the summer of $1851 \ldots$ had an opportunity of watching ... the direction of the tides; the flood invariably came from the northward, and the ebb returned in that direction (as shown in my chart of 1851) thus proving clearly that there was a water communication between Victoria Strait and Peel Sound to the northward.

Evidently, Rae accepted the theory that Victoria Strait was part of a navigable Northwest Passage.

Rae did not ask for the opportunity to speak at the select committee's hearings. However, both Murchison and the newly appointed hydrographer of the Royal Navy, Captain John Washington, gave testimony on Franklin's behalf. To reinforce the points they made, Lady Franklin addressed a letter to the committee (in United Kingdom, House of Commons, 1855:xviii), in which she argued that Peel Sound and Victoria Strait were parts of "a more navigable passage" than the ones found by McClure.

The first witnesses were Back and Kellett, who both supported McClure. Back declared that if the Investigator had been equipped with a steam engine, McClure would probably have got through, and he insisted that McClure had not only found but "made" the passage, ignoring all cavils about the fact that the Investigator had been abandoned. Kellett stated that McClure had priority of discovery over Collinson, but did not address Franklin's possible claim. 
He agreed with a committee member's suggestion that, "geographically speaking," McClure had "performed" the passage, but denied that steam power would have brought the Investigator through (in United Kingdom, House of Commons, 1855:5).

On the second day, James Ross argued that Parry, Franklin, Richardson, and McClure were joint discoverers of McClure's passages, and slyly pointed out that McClure was not the first to journey from ocean to ocean through the Arctic, since a small party of the Investigator's men, led by Samuel Gurney Cresswell, had preceded the others and arrived in England in 1853. Captain Washington then spoke in favour of Franklin, describing Victoria Strait as the final "link" and "the only portion required to solve the problem." However, Washington had to admit that McClure had traveled right through the archipelago, while Franklin had not (in United Kingdom, House of Commons, 1855:11).

Next came McClure's own testimony. He declared that he would have made the passage with the aid of steam; that even without it the Investigator could have got through in 1854; and that if he had received no aid from Kellett, he would still have made his escape without losing more than a few men (in United Kingdom, House of Commons, 1855:1618). However, these claims were firmly contradicted by Dr. William Domville of the Resolute and by Rear Admiral W.A.B. Hamilton, the secretary of the Admiralty. Hamilton put it tactfully, and yet with the utmost clarity, when he suggested (in United Kingdom, House of Commons, 1855:25) that McClure's very courage and determination had led him to take "a more sanguine view...than the facts and circumstances warranted."

Murchison testified on the final day. He began by stating (in United Kingdom, House of Commons, 1855:18-19) that McClure was entitled to a reward for being the first to have "gone through...in attempting to make that passage." Nevertheless, in his view, "that those men whose relics were found near the mouth of the Back River have effected what must be called a North-west Passage, cannot be doubted." Murchison admitted that Franklin's men had not reached Chantrey Inlet in a ship; but, he argued, how did that make their case different from McClure's? Murchison also read from Beaufort's strongly worded memo (in United Kingdom, House of Commons, 1855:20): "Let due honours and rewards be showered on the heads of those who have nobly toiled in deciphering the puzzling Arctic labyrinth... but let the name of discoverer of the North-west Passage be for ever linked to that of Sir John Franklin." Murchison suggested that McClure should not be commended for having discovered "the" Northwest Passage-a move that was all the more logical because McClure himself had found two passages. The last word went to Collinson, who affirmed (in United Kingdom, House of Commons, 1855:31 - 32) that Victoria Strait was "the only way in which the passage can be made."

The committee's report duly and cautiously stated that McClure and his men were "undoubtedly the first who have passed by water from sea to sea, and have returned to this country a living evidence of the existence of a North-west Passage" and that they had completed "the last link in the chain of discovery." Whether Franklin had a superior claim was described as a matter on which the committee could not judge (United Kingdom, House of Commons, 1855:iii, vi, viii-ix).

A few months later, Richardson (1856) wrote a short biography of Franklin for the new edition of the Encyclopaedia Britannica. He borrowed the term used in the committee's report when he declared that Franklin and his men had forged the "last link" with their lives. Lady Franklin had her heart set on a monument naming Sir John as the passage's discoverer, since a mere committee report would "be as air, when set against such an imperishable record" (Cracroft, 1855b). Then there was the hope of finding Franklin's journals. An expedition down the Back River led by James Anderson of the HBC found traces of the lost explorers but no documents. When this unsatisfactory result was announced in January 1856, Lady Franklin and many others refused to accept it as final.

\section{McCLINTOCK, THE PEEL SOUND THEORY, AND FRANKLIN AS THE TRUE DISCOVERER}

The conclusion that Franklin had passed through Peel Sound was not universally accepted. The geographer John Brown had deduced that there must be a strait between Victoria Island and Prince of Wales Island. Immediately after Collinson's return, Brown suggested this theory to him, and Collinson agreed that it was quite plausible (see Pim, 1856:213). Collinson (1855:202) then referred to the possibility of a new strait in his report to the RGS. The idea was also taken up by geographer Alexander Findlay (1856) and naval officer Alexander Becher (1856).

The young Arctic officers George Richards (1856) and Bedford Pim (1856) were not entirely convinced by Brown, who maintained (in Pim, 1856:212) that Kennedy's report about Peel Sound was probably correct. Instead, Richards favoured an attempt by Peel Sound, with sledge journeys to investigate the possible new strait. Pim thought two ships should be sent out, one by Collinson's route and one by Peel Sound, while another party descended the Back River in boats.

McClintock, who after serving under James Ross in 1848-49 had made extensive sledge journeys during Austin's and Belcher's expeditions, was also thinking about a new search, and Lady Franklin favoured him as leader (Cracroft, 1855a). Because the government declined to act, and McClintock therefore led a small private expedition, there was no possibility of sending out more than one ship. But in any case, McClintock appeared interested only in Peel Sound. During a lecture (1857a:195), he explained that in 1849, "we travelled down along the leeward side of the strait, where all the ice-pressure was most apparent," but in 1851 Browne, on the windward side, had observed smooth ice near shore, "so as to show that water must have existed the previous autumn." 
McClintock's published plan (1857b) stated that he would attempt to pass through Peel Sound and if unsuccessful would try Bellot Strait. His aim was to reach Victoria Island and winter there, then sledge to King William Island. From his Victoria Island base, he could easily return home via the Bering Strait. In other words, McClintock hoped not only to determine Franklin's fate but to navigate the Northwest Passage. His plan did not specify which route he would take between Peel Sound and Victoria Island, but after the expedition he claimed (1859b:313, 315-316) that he had never intended to try Victoria Strait. Instead, he recounted that Rae's 1854 discovery had inspired him to consider a route east of the island.

In 1858, McClintock's Fox advanced only 25 miles into Peel Sound before being blocked by ice. After several attempts in Bellot Strait, he finally reached its western end, only to find the exit sealed off by the Peel Sound pack. To the north, McClintock (1859b:196) saw ice "of more than one winter's growth, apparently immovable in consequence of the numerous islets and rocks which rise through and hold it fast." To the south the ice was "much more broken up." McClintock patiently waited until late September, when only four miles of ice separated him from open water to the south. As if to acknowledge the different conditions north and south of his position, he gave the southern passage its own name, Franklin Channel, later changed to Franklin Strait (McClintock, 1869:168).

McClintock turned back and wintered at the eastern end of Bellot Strait. In the autumn of 1858 his plan (1859b:200) was to sledge to the mouth of the Back River, examining one side of King William Island on his outward journey and the other on his return journey. Allen Young would chart the unknown shores of Peel Sound and Franklin Strait while William Hobson completed the survey of the continental coast by traveling south along Boothia. Then there was the matter of Brown's supposed new straitalthough McClintock curiously did not mention Brown as the originator of this theory. Once their first tasks were completed, Young was to follow the southwestern shore of Prince of Wales Island and Hobson the northeastern shore of Victoria Island, to determine whether such a strait existed.

On a preliminary trip to Boothia early in 1859 , McClintock himself completed the continental survey. From the Inuit, he learned $(1859 \mathrm{~b}: 234,251)$ that Franklin's ships had been abandoned off the west coast of King William Island. McClintock then altered the plan (1859b:255), assigning Hobson the task of searching this coast from north to south, while he himself would examine the straits between Boothia and King William Island, proceed to the Chantrey Inlet area, then return up the west coast of King William Island, so that it would be searched twice. In his narrative McClintock declared (1859b:313-314) that his observations on this journey reinforced his pre-existing belief in a navigable channel east of the island, but it seems possible that his original hypothesis was weaker than he admitted, and that the theory took on new importance when the Inuit told him the eastern straits were open every summer. By the time McClintock received Hobson's and Young's reports, his bias in favour of the eastern route was strong.

From the northwest coast of King William Island, Hobson observed that the ice was "very rough, and crushed up into large masses" (quoted in McClintock, 1859b:341). McClintock himself wrote in the first edition of his narrative $(1859 \mathrm{~b}: 314,341)$ that Victoria Strait was "full of" and "choke[d] up" with such ice; in a later edition (1869:299) he modified his statement somewhat, writing merely that "a large proportion" of the ice in the strait was of an exceptionally rough nature. However, in a part of Hobson's report not quoted by McClintock, the former observed (in Stenton, 2014:519) that although the ice pressure along the coast was often severe, the "general character" of the ice itself was "not particularly heavy; I can only remember one place where there was ice which bore the appearance of age." McClintock had previously insisted his own observations made on the leeward side of Peel Sound in 1849 were less valid than those made by Browne on the windward side. Yet he declared (1859b:314) that Victoria Strait was unnavigable based on selective reporting from the leeward side, even though Rae and Collinson had drawn no such conclusion from the windward side.

Young traveled along the coast of Prince of Wales Island as far as, and a little beyond, the point reached by Osborn from the other direction in 1851, thus confirming the existence of Brown's new channel. According to McClintock (1859b:338), Young was convinced the channel was "quite unnavigable" because of the "continuous icestream" pushed through it by the winds and current. The clear implication was that Franklin could not have taken that route.

According to McClintock's reconstruction (1859b:341), in 1846 Peel Sound and Franklin Strait were not just barely navigable but quite open. Then, "leaving clear water behind him," Franklin "pressed his ships into the pack when he attempted to force through Victoria Strait." The result was a combination of triumph and tragedy, made even more tragic in retrospect by the knowledge of how "very different the result might and probably would have been" if only Franklin had "known of the existence of a ship-channel, sheltered by King William Island." This sheltered channel, McClintock declared, was the final link of the only navigable Northwest Passage. But the way to it was through Peel Sound, which McClintock himself had failed to navigate. Not until years later (1875) did McClintock plainly admit that at most Peel Sound was open only once every four or five years. Whether such a route could really be considered navigable was a question he preferred to avoid.

Moreover, Young's report (1859) was less categorical than McClintock's summary of it. Young wrote that it did not seem impossible for a ship to drift through M'Clintock Channel with the ice, and his comments show a clear reluctance to generalize from the observations of one journey. Sixteen years later, after leading an expedition 
of his own to the area (see below), Young publicly stated (1875a) that whether Franklin went by Peel Sound or M'Clintock Channel was "not known" (see also Young, 1875b).

Hobson retrieved the famous Franklin record at Victory Point, King William Island. It consisted of two messages. The first was written by Graham Gore at the outset of a sledge journey in May 1847. The key fact it revealed was that Erebus and Terror spent the expedition's second winter in the ice in latitude $70^{\circ} 05^{\prime} \mathrm{N}$, longitude $98^{\circ} 23^{\prime} \mathrm{W}$ - that is, just north of King William Island. The second message, written by James Fitzjames in April 1848, added that the ships had been beset since 12 September 1846, that Franklin had died on 11 June 1847, and that the vessels had been abandoned five leagues (approx. $28 \mathrm{~km}$ ) north-northwest of Victory Point. The survivors planned to start for the Back River the next day. McClintock (1859b:274-278) found a skeleton a few miles beyond Cape Herschel, proving that during the retreat Franklin's men passed the Dease and Simpson cairn.

The first part of the Victory Point record offered the tantalizing possibility that Cape Herschel had been reached during the May 1847 sledge trip, and that Gore had returned and reported the good news before Franklin's death. McClintock subscribed, though only tentatively, to this version of events (1859b:286, 1869:257, 267). However, he was quite uncompromising in his statements (1859b:316, 1869:267) that Franklin had discovered the Northwest Passage, even if it was not the navigable passage.

There were some protests against McClintock's theories. When he told his story at a meeting of the RGS, Belcher (in McClintock, 1859a:8-9) opined that Franklin had reached King William Island by way of M'Clintock Channel, and that if he had followed the western shore of Victoria Strait he might have got through. Privately, Richardson (1859) agreed about Franklin's route, but he mildly observed that "as no one can be so well qualified as [McClintock] is to form a correct judgement on this point I readily defer to his opinion." Others may well have shared this reluctance to challenge McClintock.

Only Brown publicly dissented at any length. He observed that M'Clintock Channel was both wide and, as the heavy ice floating in it indicated, deep. "Through such a channel," Brown wrote (1860:31), "there must be...at times, a passage practicable for ships." The amount of pack would naturally vary from year to year, perhaps giving Franklin an opportunity. Nevertheless, Brown conceded that Franklin had more likely been beset in Viscount Melville Sound and carried unwillingly down M'Clintock Channel.

That both M'Clintock Channel and Peel Sound contained heavy ice in 1846 seems highly likely, given that neither of them was ever observed in anything approaching a navigable condition during the search period. In Peel Sound, Franklin's ships would have been immobilized by ice such as the search parties reported. But in the far wider M'Clintock Channel, the current and the prevailing northwest winds could have carried the trapped ships to
King William Island. It generally was-and still isassumed that Erebus and Terror were beset in the same spot where they wintered in 1846-47, but Brown (1860:32-33) correctly pointed out that this was not stated in the Victory Point record. The location of the wintering was given by Gore in 1847 and the date of besetment by Fitzjames in 1848 , and there was accordingly no clear implication that the ships had been trapped north of King William Island on 12 September 1846. Moreover, if Franklin deviated significantly from his original plan by turning southward to the east, rather than to the west, of Cape Walker, it is strange that neither officer mentioned this fact. Brown showed excessive dogmatism by insisting that Franklin undoubtedly took M'Clintock Channel; nevertheless, his arguments have merit, and it seems reasonable to consider the question of Franklin's route as unresolved-and perhaps unresolvable (see also Hickey et al., 1993).

Although Brown's reconstruction was plausible, it won no favour with his countrymen. According to Brown, Franklin had been caught helplessly in the ice and current, then carried to the southeast, where he had no wish to go. McClintock, in contrast, portrayed Franklin as carrying out his plans with initial luck as he passed triumphantly through Peel Sound. Then, faced with the barrier of ice in Victoria Strait, Franklin had supposedly refused to abandon his chosen path. McClintock's version was supported by Charles Weld, the secretary of the Royal Society, who was Franklin's nephew by marriage. According to Weld (1860:226), in 1845 Franklin had taken a map and "pointed...to the western entrance of Simpson Strait," saying, "If I can but get down there, my work is done; for from thence it would be all plain sailing to the westward." Weld never mentioned this alleged comment until early 1860, and it is incompatible with what Franklin himself wrote in 1845 . However, the anecdote reinforced McClintock's telling of Franklin's story as one of success followed by tragedy. It was accordingly repeated by McClintock's friend Osborn (1860:45) and many other writers.

Reviewers of McClintock's book readily accepted his claim that because Franklin's expedition had been the first to prove there was a water connection, Sir John was the true discoverer (e.g., Anon., 1860a:151; Lushington, 1860:275). A few letters were written to the press on McClure's behalf, but McClure himself, though bitterly resentful, remained silent. In 1860 the RGS awarded its gold medal to Lady Franklin, in recognition of the fact that her husband had "in a geographical sense, firmly established the existence of a North-West Passage" (Anon., 1860b:xcv). In 1866 a statue funded by a government grant commemorated Franklin as the discoverer, depicting him at the moment when he announced to his crew that the passage's existence was confirmed (Anon., 1866).

McClure (1860) believed that his opponents could "never do away with" his feat of crossing the archipelago. He was not wrong, for after his death the Times (Anon., 1873) praised him for both "discovering and completing" 
the passage. This tribute drew an immediate response from Lady Franklin (1873), who extolled McClure's feats of navigation but insisted on her husband's priority as the discoverer, citing the RGS award as proof that high authorities had acknowledged Sir John's claim. McClure's cause was taken up with passion by Alexander Armstrong, who had served as the Investigator's doctor.

Armstrong (1873a) accused Murchison and others of having indulged "the weakness or the ambition" of Lady Franklin, to McClure's detriment. He argued (1873b) that only if survivors from Erebus and Terror had been rescued and brought home by Collinson could Franklin be said to have discovered a passage. McClintock (1873) ended the dispute by observing that he had seen both M'Clure Strait and Victoria Strait and was convinced that neither would ever be navigated. Instead, "the only way to accomplish the transit by ship" lay east of King William Island.

Two years later Lady Franklin died, having secured for her husband a memorial in Westminster Abbey that described him as the discoverer. Yet the issues of navigability and actual navigation, so pointedly raised by McClintock in 1873, remained to haunt advocates of both Franklin and McClure. George Richards concluded that neither man was the discoverer. "In awarding the palm," he wrote (in Collinson, 1889:x-xi), "a compromise was offered which history will not ratify; but will probably pronounce the verdict that the Passage has not been accomplished at all."

\section{THE QUESTION OF NAVIGABILITY}

At the end of the Franklin search, four Northwest Passages had been geographically discovered-that is, two or more explorers had traveled from one end of each passage to the other by various combinations of ship, boat, and foot travel.

1. Lancaster Sound, Barrow Strait, Peel Sound (or Lancaster Sound, Prince Regent Inlet, Bellot Strait, Peel Sound), Franklin Strait, Victoria Strait, and the western Arctic coastal waters.

2. Lancaster Sound, Barrow Strait, Viscount Melville Sound, and Prince of Wales Strait.

3. Lancaster Sound, Barrow Strait, Viscount Melville Sound, and M'Clure Strait.

4. Lancaster Sound, Barrow Strait, Peel Sound (or Lancaster Sound, Prince Regent Inlet, Bellot Strait, Peel Sound), Franklin Strait, James Ross Strait, Rae Strait, Simpson Strait, and the western Arctic coastal waters.

Note that Davis Strait and Baffin Bay on the east and the Bering Strait, Chukchi Sea, and Beaufort Sea on the west are common to all the above routes. Bellot Strait is here considered as a variation on the Peel Sound routes because whether ships could pass through its western end depended on ice conditions in Peel Sound. Franklin might have reached Victoria Strait by Viscount Melville Sound and M'Clintock Channel, while Hudson Strait, Fury and Hecla Strait, the Gulf of Boothia and Prince Regent Inlet provided a possible alternative to Baffin Bay and Lancaster Sound. Though these water connections were known, neither route was generally considered as part of a Northwest Passage.

None of the passages had been navigated from end to end. Therefore, in the terminology used in 1818, they had been found out but not sailed through, and hence not discovered as navigable passages. Yet because there was no more geographical finding out to do along the four routes, anyone sailing from ocean to ocean would not meet both original criteria. It was a strange and paradoxical situation. Several passages had been mapped, yet no explorer could make an unchallengeable claim to have discovered a passage. Nor, even though navigation was the missing element, could anyone establish a true discovery claim by navigating.

Whether the passages were navigable was a matter for speculation. By two different routes, McClure had brought the Investigator very close to waters sailed by Parry's Hecla and Griper. Collinson's Enterprise had almost reached the spot where Erebus and Terror were abandoned. Only in the fourth passage was there a major gap of navigation, since at least the distance from the bottom of Franklin Strait to Cambridge Bay, and possibly more, remained unsailed by ships. Nevertheless, most historians have followed McClintock, assuming that this fourth passage was the most navigable, and indeed that it was probably the only navigable passage for sailing ships. The fact that in 1903-06 Amundsen found Peel Sound open and took his vessel, the sloop Gjøa, east of King William Island and then to the Bering Strait naturally reinforces this view.

However, sloops have only one mast and are classified as sailboats, not ships. The 57-ton (Kjær, 2005:355) Gjøa was tiny compared to the ships used in 19th-century British exploration, which were themselves not large by naval standards. Horatio Nelson's Victory was more than 3000 tons, and the last wooden battleships, launched in the 1850s, were close to 7000 tons (Parkes, 1957:7). Hecla, Griper, Erebus, and Terror were 375, 180, 372, and 326 tons, respectively (Parry, 1821:i; Pearsall, 1973:782), while Investigator was 480 tons and Enterprise, 530 tons (Stein, 2015:18). Franklin might have sent boat or sledge parties to James Ross Strait and Rae Strait in 1846-47, but as Woodman (1991:75) has pointed out, he would surely have considered this route unnavigable for his ships (see also Potter, 2012). Accordingly, the Gjøa's exploits in such shallow coastal waters did not fulfil the requirements set out in 1818.

Climate is another important factor bearing on the question of navigability. Scientists from the Polar Continental Shelf Project, which began in the late 1950s, were able to outline the fluctuations in the Canadian Arctic's climate over the preceding 700 years through melt layers and pollen concentrations in ice cores from the Devon Ice Cap. Their data showed that the decades between 1810 and 1860 were among the coldest periods in 
that entire time span. Conditions were at their very worst in the 1840 s and 1850s. Immediately after the Franklin search, temperatures began to rise, and by the 1960s they were well above the 700-year average (Alt et al., 1985: fig. 12). The impact of ice conditions on navigation was therefore anything but a constant factor. Clearly, passages that were not navigable during the main period of British Arctic exploration must have been so, to varying degrees, at other times. Between 1859 and 1950, most summers had temperatures slightly above the 700 -year average. Reports from expeditions in this period are accordingly a better source regarding navigability than those written between 1818 and 1859.

\section{VOYAGES AFTER 1859}

On the route advocated by McClintock, the first attempt was made by his former subordinate Young in Pandora. In 1875 Young sailed down Peel Sound to a point just north of Bellot Strait, where from a hill he saw (1879:56) "one unbroken pack extending from shore to shore, and as far as the visible horizon to the southward." Convinced that Peel Sound was rarely open, Young feared to winter in the strait because he might not get out the next year.

Young was followed by Amundsen in 1903. In what the Inuit later told him was an exceptionally open season, Amundsen (1908I:55, 58-59, 215) was amazed to encounter almost no ice in Peel Sound. Navigation through James Ross Strait proved difficult, and the Gjøa twice went aground there (1908I:62-70). Simpson Strait also posed a serious challenge, and Amundsen (1908II:119) described the eastern part of Queen Maud Gulf as "a most disconcerting chaos" of rocks and reefs, where "we bungled through zigzag, as if we were drunk."

In his journal (2017:517), Amundsen wrote that he had completed the "missing link" when he reached Cambridge Bay, but in his narrative (1908II:123 - 126) he nevertheless depicted himself as wracked with anxiety about whether the passage would be accomplished until the moment he sighted a whaling ship off Banks Island. Amundsen mistakenly believed that McClure and Rae had jointly been given the monetary award for discovering the passage, and in his autobiography (1927:61), he explained that while both these men deserved rewards "for their hardships and achievements," his own voyage was "the first and only actual navigation" of the entire passage. Although he had formerly (1908I:48-49) named Franklin and his men as the first discoverers, it seems that he actually considered this title his own.

Amundsen (1908II:106) rated Collinson's contribution higher than McClure's because McClure's routes were never navigable. However, the observations of another explorer contradicted the assertion about McClure. In 1906, Joseph-Elzéar Bernier (1909:19) found the ice at the eastern end of M'Clure Strait "not much heavier" than elsewhere, with "openings all along the land of Melville Island as far west as we could see." In 1908, from the same position, he saw no ice at all. Wintering on Melville Island, Bernier (1910:38, 80-81, 85) observed some open water in the strait as late as October. One of his officers, Octave Morin, made a sledge journey to Prince of Wales Strait, where he found smooth new ice, indicating open water the year before (Bernier, 1910:133). Ignoring the dangers on the west coast of Banks Island, Bernier wanted to try the passage by this route, but when he again sailed to M'Clure Strait, he found dramatically different conditions. Second officer Robert Janes, who was in the crow's nest, commented: "I never saw such ice; it must have been 50 to 60 feet thick" (quoted in Bernier, 1911:29).

In 1915, Vilhjalmur Stefansson tried to take his schooner Polar Bear through Prince of Wales Strait, but he was stopped by ice and wintered on Victoria Island. However, sledge parties reported only young ice in Viscount Melville Sound, and over the next few years Stefansson's observations convinced him (1921:430-431) that the sound was navigable "at least two years out of three" and that the passage could likely be made through Prince of Wales Strait "quite as easily" as by Amundsen's route. In 1916 Stefansson proceeded north by sledge and ordered Polar Bear's captain, Henry Gonzales, to take the ship to Melville Island. Gonzales did not, later claiming that the ice had been too heavy, but another expedition member reported that Prince of Wales Strait had in fact been ice-free and that Gonzales was simply afraid to go so far north (Noice, n.d.:208, 242).

In 1940, when Henry Larsen was instructed to sail through the passage from west to east in the 80-ton schooner St. Roch, his first plan was to try Prince of Wales Strait. Circumstances made this impossible, so he settled for Amundsen's route. Near King William Island navigation was difficult, especially in James Ross Strait, and ice conditions on the west coast of Boothia were exceptionally bad. Larsen was forced to winter at Pasley Bay, Boothia, in 1941-42. In the summer of 1942 the ice was again extremely heavy. With great difficulty, Larsen made his way to Bellot Strait. At first the strait seemed like an icefree refuge, but disaster nearly struck when the current swept floes from Peel Sound in just behind the ship and more pack was sighted ahead (Robinson, 1945:54, 59-65; Larsen, 1954:24-25).

In 1944, sailing from east to west, Larsen met broken but closely packed ice in Viscount Melville Sound, which he avoided by a detour north of Byam Martin Island. M'Clure Strait was filled with the heaviest floes seen on the voyage, but Prince of Wales Strait was reached without much difficulty. From that point on it was clear sailing (Robinson, 1945:66-73; Larsen, 1954:39-45). Larsen not only became the first navigator to make a passage in one season: he did it in an astonishing 18 days. But, as Larsen (in Robinson, 1945:73) cautioned, "Our voyage showed that the Northwest Passage can be traversed in a single year, but does not prove that this could be accomplished every year." 


\section{VICTORIA STRAIT AFTER 1859}

As Dunbar (1985) pointed out, after 1859 ship expeditions avoided Victoria Strait as if it were cursed, so it is impossible to know how much conditions there varied during the 19th century. Dunbar, a leading expert on Arctic ice, was evidently skeptical of the common assumption that navigating the strait had been utterly impossible, and she noted (1985:120) the influence of McClintock's report, which made it difficult for others to believe "that the ice could have been different" in some years.

Even in the early part of the 20th century, Victoria Strait was seldom visited. By the 1960 s, it was often navigable and occasionally ice-free (Alt et al., 1985: fig. 8). It is now the most commonly used passage except for large vessels (Headland, 2017:1).

In 2014 Erebus was found in Wilmot and Crampton Bay on the southeastern side of Queen Maud Gulf. Two years later, Terror was also found, in Terror Bay on the southwest coast of King William Island. Both ships, therefore, survived the most constricted part of Victoria Strait, near the Royal Geographical Society Islands. The wreck of Terror is in remarkably good condition. While the wreck of Erebus is less so, the fatal damage was evidently done after Victoria Strait was left behind. These finds prove that even in the 1840s and 1850s ships could pass through the supposedly unnavigable strait without being destroyed. It is possible that, as Woodman (1991) speculated, some of Franklin's men returned to the vessels and sailed them southward after ice conditions eased. However, even if this was the case, the survivors never reached previously navigated waters.

\section{CONCLUSION}

Ship expeditions between 1859 and 1950 were too infrequent to yield conclusive data, and they tell us nothing at all about Victoria Strait. However, they certainly suggest that under average conditions the passage through Prince of Wales Strait was just as reliably navigable as Amundsen's route, and quite possibly more so. Prince of Wales Strait was the link sought by Franklin; it is reasonably well sheltered from the Beaufort Sea ice; its depth gives it a significant advantage over the route east of King William Island; and the passage through it and Parry Channel was almost completely navigated during a period when Arctic climate was at its coldest. Parry and McClure were the joint discoverers of this passage. Parry has long been among the most renowned polar explorers, but McClure deserves more recognition than he has received from historians.

There is sometimes a tendency for historians to bestow the status of true discoverer on explorers they particularly admire. For example, Neatby (1958:182) wrote that "for daring and sheer achievement Franklin stands alone; and succeeding generations have rewarded him in associating his name pre-eminently with the Passage"-a view in which Neatby entirely concurred. McGoogan (2001:190) alleged that Simpson's death was providential because it prevented an unworthy man from finding the passage. In his opinion (2001:305), it was only right for Rae- "a peerless figure"- to reveal the Arctic's "ultimate secret." McGoogan (2001, 2005, 2017) put forward a dramatic narrative in which the machinations of Lady Franklin and her supporters were directed not against McClure, but against Rae - even though Rae had never claimed to be the discoverer. McGoogan's books feature such inaccuracies as the statements that Victoria Strait was "forever impenetrable to sailing ships" (2001:169) and that Larsen's voyage through Prince of Wales Strait was possible only because he "relied almost entirely" on St. Roch's engine (2001:258).

McClure's character, in contrast to Parry's, Franklin's, and Rae's, is not admirable from any point of view. He was callous, vindictive, and obsessively ambitious; his only good traits were courage and superb seamanship. Yet the entire process of European discovery, in the Arctic and elsewhere, is now generally viewed with cynicism. McClure was no hero, but do we really still need supposedly flawless heroes? It should surely be possible to point out the virtues of the route he discovered without any implication that he himself deserves to be admired.

\section{REFERENCES}

Alt, B.T., Koerner, R.M., Fisher, D.A., and Bourgeois, J.C. 1985. Arctic climate during the Franklin era, as deduced from ice cores. In: Sutherland, P.D., ed. The Franklin era in Canadian Arctic history, 1845-1859. Mercury Series, Archaeological Survey of Canada Paper 131. Ottawa: National Museum of Man. 69-92.

Amundsen, R. 1908. The North West Passage, 2 vols. London: Archibald Constable.

. 1927. My life as an explorer. Garden City, New York: Doubleday.

2017. Roald Amundsen's diary from the Northwest Passage. Oslo: Fram Museum.

Anon. 1853. The discovery of the North-West Passage. Times, 2 November 1853:12.

. 1860a. Presentation of the gold medals to Lady Franklin and to Captain Sir F.L. M'Clintock. Journal of the Royal Geographical Society 30:xci-xcix.

. 1860b. The fate of Franklin. Good Words 1(8, 9, 10):113-116, 137-139, 149-151.

. 1866. Statue to Sir John Franklin. Times, 16 November 1866:10.

1873. Naval and military intelligence. Times, 22 October 1873:5.

Armstrong, A. 1873a. Letter to the editor. Times, 31 October 1873:6.

1873b. Letter to the editor. Times, 5 November 1873:7. 
Back, G. 1836. Narrative of the Arctic land expedition to the mouth of the Great Fish River, and along the shores of the Arctic Ocean, in the years 1833, 1834, and 1835. London: John Murray.

- 1838. Narrative of an expedition in H.M.S. Terror, undertaken with a view to geographical discovery on the Arctic shores, in the years 1836-7. London: John Murray.

Barr, W. 2000. Richard Cyriax's note concerning Thomas Simpson's claim of having discovered the Northwest Passage. Polar Record 36(197):113-116. https://doi.org/10.1017/S0032247400016211

- 2007. Arctic hell-ship: The voyage of HMS Enterprise 1850 - 1855. Edmonton: University of Alberta Press.

- 2016. Searching for Franklin where he was ordered to go: Captain Erasmus Ommanney's sledging campaign to Cape Walker and beyond, spring 1851. Polar Record 52(4):474-498. https://doi.org/10.1017/S0032247416000188

Barrow, J., Richardson, J., Franklin, J., Beaufort, F., and Ross, J. 1836. Communications on a North-West Passage, and further survey of the northern coast of America. Journal of the Royal Geographical Society of London 6:34-50.

[Becher, A.B.]. 1856. Reflections on Sir John Franklin's expedition, and where his ships were most probably beset in the ice. Nautical Magazine 25(3):121-147.

Bernier, J.-E. 1909. Report on the Dominion Government Expedition to [the] Arctic Islands and the Hudson Strait on board the C.G.S. "Arctic," 1906-1907. Ottawa: King's Printer. . 1910. Report of the Dominion of Canada government expedition to the Arctic islands and Hudson Strait on board the D.G.S. "Arctic." Ottawa: Government Printing Bureau.

- 1911. Report on the Dominion government expedition to the northern waters and Arctic archipelago of the D.G.S. "Arctic" in 1910. [Ottawa].

Brown, J. 1860. The North-West Passage, and the plans for the search for Sir John Franklin. A review, with maps, \&c. Second edition, with a sequel, including the voyage of the "Fox." London: E. Stanford.

Browne, W.H. 1851. Report of the Proceedings of the Sledge "Enterprise," in charge of Lieut. W. H. Browne, Her Majesty's Ship "Resolute," commencing 15th April, ending 28th May 1851. In: Additional papers relative to the Arctic expedition under the orders of Captain Austin and Mr. William Penny. London: G.E. Eyre and W. Spottiswoode. 65-75.

Collinson, R. 1854. Letter to J. Barrow Jr., 4 July 1854, British Library, Additional Manuscripts 35308, ff. 20-22.

- 1855. Account of the proceedings of H.M.S. Enterprise from Behring Strait to Cambridge Bay. Journal of the Royal Geographical Society of London 25:194-206.

- 1889. Journal of H.M.S. Enterprise, on the expedition in search of Sir John Franklin's ships by Behring Strait, 1850-55. Edited by T.B. Collinson. London: Sampson Low, Marston, Searle, \& Rivington.

Cracroft, S. 1855a. Letter to R. Murchison, 19 January 1855. British Library, Additional Manuscripts 46125, ff. 238-239.

- 1855b. Letter to R. Murchison, 7 July 1855. British Library, Additional Manuscripts 46125, ff.449-450.
Cyriax, R.J. 1939. Sir John Franklin's last Arctic expedition: A chapter in the history of the Royal Navy. London: Methuen.

Dunbar, M. 1985. The effect of sea ice conditions on maritime Arctic expeditions during the Franklin era. In: Sutherland, P.D., ed. The Franklin era in Canadian Arctic history, 1845-1859. Mercury Series, Archaeological Survey of Canada Paper 131. Ottawa: National Museum of Man. 114-121.

Findlay, A.G. 1856. On the probable course pursued by Sir John Franklin's expedition. Journal of the Royal Geographical Society of London 26:26-35.

Franklin, J. (Jane). 1873. Letter to the editor. Times, 28 October 1873:5.

Franklin, J. 1828. Narrative of a second expedition to the shores of the polar sea, in the years 1825, 1826, and 1827. London: John Murray.

. 1845a. Letter to J. Richardson, 7 July 1845. Gell of Hopton Hall Papers, Derbyshire Record Office, D3311/53.

—. 1845b. Letter to J.C. Ross, 9 July 1845. Scott Polar Research Institute, MS 248/316/25.

—. 1845c. Letter to W.E. Parry, 10 July 1845. Scott Polar Research Institute, MS 438/18/7.

Headland, R.K. 2017. Transits of the Northwest Passage to end of the 2017 navigation season. Cambridge: Scott Polar Research Institute.

Hickey, C.G., Savelle, J.M., and Hobson, G.B. 1993. The route of Sir John Franklin's third Arctic expedition: An evaluation and test of an alternative hypothesis. Arctic 46(1):78-81. https://doi.org/10.14430/arctic1325

Kennedy, W. 1853. A short narrative of the second voyage of the Prince Albert, in search of Sir John Franklin. London: W.H. Dalton.

Kjær, K.-G. 2005. The Arctic vessel Gjøa. Polar Record 41(4):355-361. https://doi.org/10.1017/s0032247405004663

Larsen, H. 1954. The North-West Passage, 1940-1942 and 1944. Vancouver, British Columbia: City Archives.

Lushington, F. 1860. Arctic enterprise and its results since 1815. Macmillan's Magazine 1(4):268-278.

McClintock, F.L. 1857a. Reminiscences of Arctic ice-travel in search of Sir John Franklin and his companions. Journal of the Royal Dublin Society 1(4):183-250.

1857b. Letter to S.R. Graves. Times, 4 June 1857:10.

1859a. Discoveries by the late expedition in search of Sir John Franklin and his party. Proceedings of the Royal Geographical Society of London 4(1):2-14.

— 1859b. The voyage of the "Fox" in the Arctic seas: A narrative of the discovery of the fate of Sir John Franklin and his companions, 1st ed. London: John Murray.

- 1869. The voyage of the "Fox" in the Arctic seas in search of Franklin and his companions, 3rd ed. rev. London: John Murray.

- 1873. Letter to the editor. Times, 15 November 1873:9.

1875. Letter to J.G. Bennett, 3 November 1875. New York Herald, 18 November 1875:3.

McClure, R. le M. 1860. Letter to J. Barrow Jr., 6 February 1860. British Library, Additional Manuscripts 35309, ff. 132-133. 
McGoogan, K. 2001. Fatal passage: The untold story of John Rae, the Arctic adventurer who discovered the fate of Franklin. Toronto: HarperCollins.

- 2005. Lady Franklin's revenge: A true story of ambition, obsession and the remaking of Arctic history. Toronto: HarperCollins.

- 2017. Dead reckoning: The untold story of the Northwest Passage. Toronto: HarperCollins.

McKenzie, W.G. 1975. The identity of Gateshead Island. Polar Record 17(110):545-559. https://doi.org/10.1017/S0032247400032514

Neatby, L.H. 1958. In quest of the North West Passage. Toronto: Longmans, Green.

Noice, H. n.d. [1925]. With Stefansson in the Arctic. New York: Dodd, Mead \& Co.

Osborn, S. 1851. Journal. In: Additional papers relative to the Arctic expedition under the orders of Captain Austin and Mr. William Penny. London: G.E. Eyre and W. Spottiswoode. $89-102$.

1852. Stray leaves from an Arctic journal; or, eighteen months in the polar regions, in search of Sir John Franklin's Expedition, in the years 1850-51. London: Longman, Brown, Green and Longmans.

- ed. 1856. The discovery of the North-West Passage by H.M.S. "Investigator," Capt. R. M'Clure, 1850, 1851, 1852, 1853, 1854. London: Longman, Brown, Green, Longmans, and Roberts.

. 1860. The career, last voyage and fate of Captain Sir John Franklin. London: Bradbury and Evans.

Parkes, O. 1957. British battleships, "Warrior" 1860 to "Vanguard" 1950: A history of design, construction and armament. London: Seeley.

Parry, W.E. 1821. Journal of a voyage for the discovery of a northwest passage from the Atlantic to the Pacific: Performed in the years 1819-20, in His Majesty's ships Hecla and Griper. London: John Murray.

Pearsall, A.W.H. 1973. Bomb vessels. Polar Record 16(105):781-788. https://doi.org/10.1017/S0032247400063865

Pim, B. 1856. Plan for a farther search after the remains of the Franklin expedition. Proceedings of the Royal Geographical Society of London 1(6):209-215.

Potter, R. 2012. A "navigable" Northwest Passage? Visions of the North (blog), posted on 29 September 2012. http://visionsnorth.blogspot.com/2012/

Rae, J. 1852. Recent explorations along the south and east coast of Victoria Land. Journal of the Royal Geographical Society of London 22:82-96.

- 1855a. Report to Archibald Barclay, 1 September 1854. In: Further papers relative to the recent Arctic expeditions in search of Sir John Franklin and the crews of H.M.S. "Erebus" and "Terror," London: G.E. Eyre and W. Spottiswoode. $835-844$.

- 1855b. Arctic exploration, with information respecting Sir John Franklin's missing party. Journal of the Royal Geographical Society of London 25:246-256.

- 1855c. Letter to the editor. Times, 25 June 1855:11.
Richards, G.H. 1856. Letter. Proceedings of the Royal Geographical Society of London 1(4):94-95.

Richardson, J. 1848. Letter to W.E. Parry, 25 February 1847. In: United Kingdom, House of Commons. Arctic expedition: Return to an address of the honourable the House of Commons, dated 21 March 1848. 24-26.

- 1855a. Letter to the editor. Times, 23 June 1855:5.

. 1856. Franklin, Sir John. Encyclopaedia Britannica, $8^{\text {th }}$ ed.

1859. Letter to J. Franklin, 11 October 1859. Scott Polar Research Institute, MS 1503/59.

Robinson, J.L. 1945. Conquest of the Northwest Passage by R.C.M.P. schooner St. Roch. Canadian Geographical Journal 30(2):52-73.

Ross, J.C. 1848. Search proposal, 2 December 1847. In: United Kingdom, House of Commons. Arctic expedition: Return to an address of the honourable the House of Commons, dated 21 March 1848. 29-30.

Savours, A. 1999. The search for the North West Passage. New York: St. Martin's Press.

Simpson, A. 1845. The life and travels of Thomas Simpson, the Arctic discoverer. London: Richard Bentley.

Simpson, T. 1843. Narrative of the discoveries on the north coast of America; effected by the officers of the Hudson's Bay Company during the years 1836-39. London: Richard Bentley.

Stefansson, V. 1921. The friendly Arctic: The story of five years in polar regions. New York: Macmillan.

Stein, G.M. 2015. Discovering the North-West Passage: The fouryear Arctic odyssey of H.M.S. Investigator and the McClure expedition. Jefferson, North Carolina: McFarland \& Company.

Stenton, D.R. 2014. A most inhospitable coast: The report of Lieutenant William Hobson's 1859 search for the Franklin expedition on King William Island. Arctic 67(4):511 - 522. https://doi.org/10.14430/arctic4424

United Kingdom, Admiralty. 1848. Orders to J. Franklin. In: United Kingdom, House of Commons. Arctic expedition: Return to an address of the honourable the House of Commons, dated 21 March 1848. 3-7.

United Kingdom, House of Commons. 1855. Report from the select committee on Arctic exploration.

United Kingdom, Parliament. 1818. An act for more effectually discovering the longitude at sea, and encouraging attempts to find a northern passage between the Atlantic and Pacific Oceans, and to approach the northern pole. 58 Geo. III, c. 20.

. 1821. An act to amend an act of the fifty-eighth year of his late majesty, for more effectually discovering the longitude at sea, and encouraging attempts to find a northern passage between the Atlantic and Pacific Oceans, and to approach the northern pole. 1-2 Geo. IV, c. 2.

United Kingdom, Privy Council. 1819. Order-in-Council, 19 March 1819. London Gazette 17461, 20 March 1819. 501-502. . 1821. Order-in-Council, 23 February 1821. London Gazette 17684, 27 February 1821:497-498.

[Weld, C.R.] 1860. Franklin's fate, and the voyage of the "Fox." Fraser's Magazine 61(362):221 - 227.

Williams, G. 2009. Arctic labyrinth: The quest for the Northwest Passage. Toronto: Viking Canada. 
Woodman, D.C. 1991. Unravelling the Franklin mystery: Inuit testimony. Montreal and Kingston: McGill-Queen's University Press.

Young, A. 1859. Report to F.L. McClintock, 17 August 1859. Library and Archives Canada, MG24 H27, microfilm reel A-34. 1875a. Letter to J.G. Bennett, 26 October 1875. New York Herald, 9 November 1875:3.

1875b. Letter to the editor. Times, 5 November 1875:4. - 1879. The two voyages of the 'Pandora' in 1875 and 1876. London: Edward Stanford. 